Review

Versi pre-print

\title{
Adaptasi Tanaman Padi Terhadap Stres Genangan: Biosintesis Etilen
}

Adaptation of Rice to Submergence Stress: Ethylene Biosyntheses

\section{Danner Sagala}

\author{
Universitas Prof. Dr. Hazairin, S.H. Bengkulu \\ Email: danner_10@unihaz.ac.id
}

\begin{abstract}
Drastically environmental change when submergence occur cause physiologically damages in plant. Submergence inhibits the rate of gas diffusion between plant and atmosphere. The decrease of oxygen interfere the respiration and the inhibition of $\mathrm{CO}_{2}$ into plant disturbs the photosynthesis process. In addition, the plant also experience stress after submergence. There are two types of plant adaptation to submergence, namely tolerance and the elongation ability. The elongation of submerged stem is related to ethylene production. The exogenous ethylene application stimulate the elongation of deepwater rice in aerobic condition. Ethylene biosyntheses is arranged by ACC synthase gene.
\end{abstract}

Key words: Rice, Gas diffusion, physiological damage, ACC synthase gene, and stress

\section{PENDAHULUAN}

Padi merupakan tanaman semi akuatik yang beradaptasi dengan baik pada kondisi rendaman parsial (Fukao \& Serres, 2008; Jackson \& Ram, 2003). Padi dikelompokkan ke dalam tiga ekotipe berdasarkan kebutuhan air dan toleransinya terhadap genangan, yaitu padi rawa (deep-water rice), padi sawah tadah hujan (low-land rice) dan padi gogo (high-land rice). Dari ketiga ekotipe tersebut, hanya padi rawa dan padi sawah tadah hujan yang telah banyak dipelajari untuk menjelaskan mekanisme toleransi genangan karena kedua kultivar ini merupakan kultivar yang ditanam di daerah yang sering mengalami banjir. Padi rawa ditanam di daerah rawa pasang surut dan di lahan sawah tadah hujan di Asia Tenggara, dimana lahan akan tergenang setingi > $1 \mathrm{~m}$ selama musim hujan (Fukao \& Serres, 2008).

Kebanyakan petani, khususnya petani sawah tadah hujan, menanam padi pada awal musim hujan, karena suplai air untuk sawah tadah hujan sangat tergantung pada air hujan. Oleh karena itu bibit padi yang masih muda sering terendam. Genangan merupakan keadaan dimana air telah mengisi semua pori-pori tanah dan berlebih hingga berada di atas permukaan tanah. Selama musim hujan maupun pasang naik pada lahan rawa, air akan menggenangi tanah dan genangan terus bertambah tinggi hingga merendam sebagian (partial submergence), bahkan seluruh organ tanaman padi (complete submergence). Penelitian- 
Review

Versi pre-print

penelitian yang telah dilakukan oleh para peneliti padi, baik yang dilakukan di lapangan maupun di laboratorium, pada umumnya dilakukan dengan mengkondisikan tanaman terendam (parsial maupun penuh) dengan mengabaikan daya dorong air yang disebut dengan disebut stagnan atau slow moving (Raskin \& Kende, 1984; Metraux \& Kende, 1984; Jackson, 2008; Kawano et al., 2008; Fukao \& Serres, 2008)

Pengaruh negatif rendaman terhadap tanaman terjadi akibat kerusakan mekanis pada daun, berkurangnya cahaya, terbatasnya difusi gas, peningkatan kepekaan tanaman terhadap hama dan penyakit. Pada saat tanaman terendam air, suplai oksigen dan karbondioksida menjadi berkurang sehingga mengganggu proses fotosisntesis dan respirasi. Bila tanaman terendam lebih dari 4 hari, lama kelamaan akan mati (Ito et al. 1999; Kawano et al. 2002; Litbang Deptan, 2007). Ram et al., (2002) menyimpulkan tiga perubahan lingkungan yang drastis pada saat banjir terjadi yang dapat mengakibatkan kerusakan secara fisiologis pada tanaman, yaitu berkurangnya oksigen yang membatasi respirasi, terhambatnya $\mathrm{CO}_{2}$ untuk masuk ke dalam tanaman yang mengganggu proses fotosintesis dan stres pasca terendam pada saat air sudah berkurang.

\section{MEKANISME ADAPTASI TANAMAN PADI}

Menurut Kawano et al., (2008) dan Fukao \& Serres (2008) ada dua tipe adaptasi tanaman terhadap genangan, yaitu toleransi dan kemampuan melakukan pemanjangan. Pemanjanangan selama genangan, yang merupakan strategi penghindaran, memampukan tanaman padi untuk memulai/melakukan metabolisme aerobik dengan mengusahakan pucuk berada di atas permukaan air. Padi sawah merespon genangan dengan pemanjangan batang (pucuk) hingga $25 \mathrm{~cm}$ per hari untuk menghindari rendaman penuh (Vriezen et al., (2003).

Fukao \& Serres (2008) menyimpulkan bahwa pertumbuhan bawah air yang cepat merupakan suatu proses boros energi yang membutuhkan konsumsi cadangan karbohidrat dan sumber energi lainnya seperti lipid dan protein. Tanaman yang terendam akan mengalami krisis energi karena kehabisan karbohidrat dan cadangan energi lainnya jika air sangat tinggi dimana pucuk tidak dapat muncul ke permukaan air. Oleh karena itu, respon penghindaran akan berhasil hanya jika organ fotosintesis dapat muncul ke permukaan sebelum cadangan energi habis. Sebaliknya, padi yang toleran genangan tidak melakukan pemanjangan dan tidak boros energi. Kultivar ini masih mampu bertahan jika terendam selama 14 hari. Diduga kultivar toleran ini hanya menggunakan cadangan karbohidrat dan 
Review

Versi pre-print

cadangan energi lainnya untuk keperluan metabolisme dasar dalam memelihara jaringan, khususnya jaringan meristematik dalam kondisi terendam.

Suatu analisa komparatif respon padi rawa (Varietas Plai Ngam) dan padi tadah hujan peka (submergence-intoleran; Varietas IR 36) terhadap genangan menunjukkan perbedaan respon diantara kedua varietas karena perbedaan kapasitas biosintesis etilen dan responsifnya. Genangan mendorong pertumbuhan pucuk sementara pada kedua varietas. Namun, pada Plai Ngam ada peningkatan harian tinggi tanaman dibandingkan IR 36 sehingga bibit Plai Ngam signifikan bertambah tinggi selama 10 hari genangan. Sesuai dengan perbedaan tersebut, jumlah transkrip ACS1 dan ACS5 dan aktifitas enzimatis ACC oksidase lebih besar pada Plai Ngam dibandingkan IR 36 selama genangan. Hal ini menunjukkan adanya relasi yang positif antara kapasitas produksi etilen dengan pemanjangan batang terendam pada tanaman padi. Bukti lain adalah, pemberian etilen eksogen signifikan merangsang pemanjangan ruas padi rawa (deepwater) pada kondisi aerobic dibandingkan kultivar non-deepwater (Fukao \& Serres, 2008).

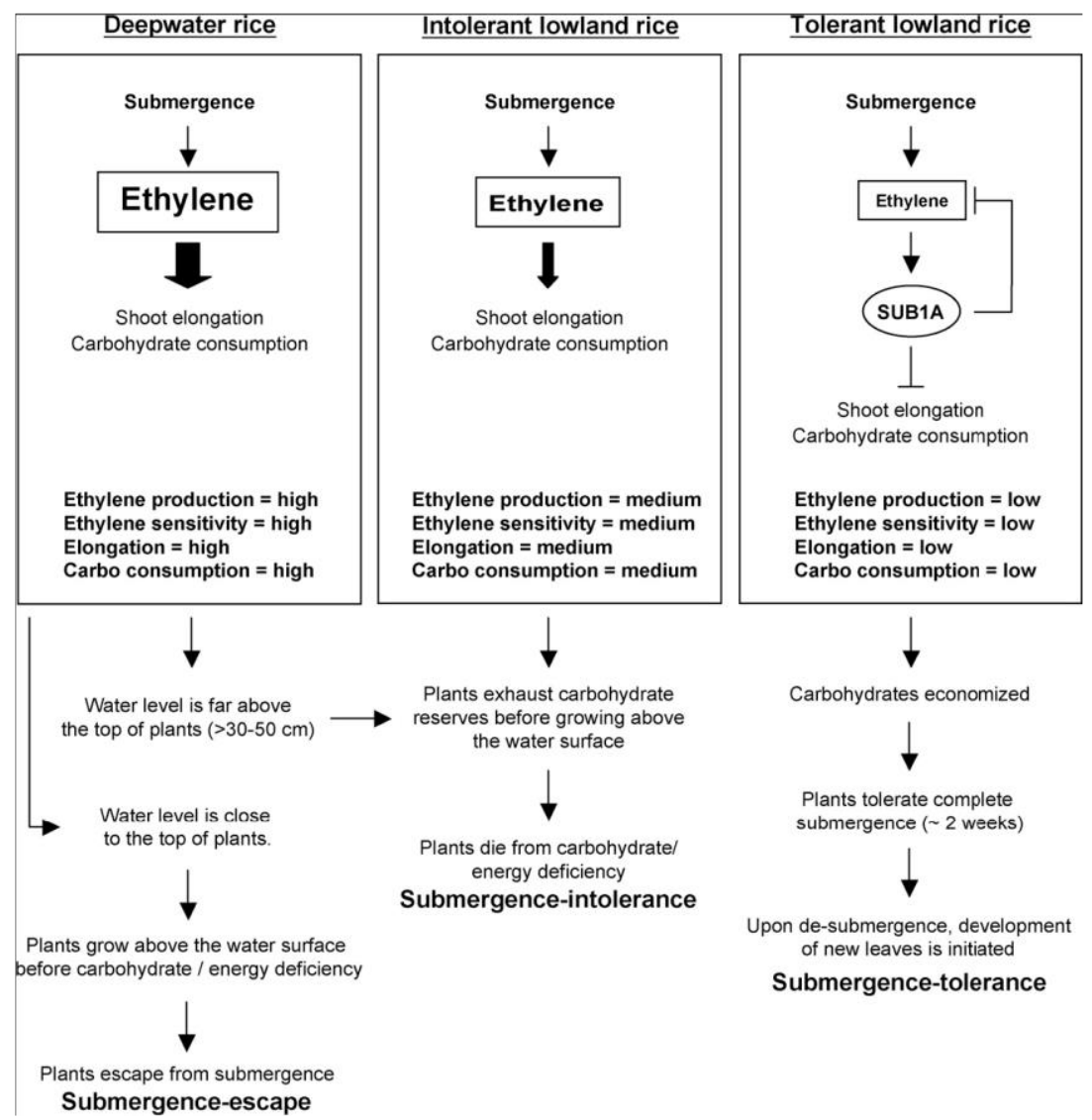

Gambar 1. Perbedaan respon padi terhadap genangan yang diatur oleh etilen (Sumber: Fukao \& Serres, 2008)

Gambar diatas menunjukkan bahwa genangan mendorong akumulasi etilen endogen yang dapat merangsang pertumbuhan tanaman dan konsumsi karbohidrat dan cadangan 
Review

Versi pre-print

energy lainnya pada padi rawa dan padi tadah hujan. Selama genangan, padi rawa lebih mampu mensintesa dan tanggap terhadap etilendari pada padi tadah hujan yang menyebabkan suatu aktifasi pemanjangan bawah air yang signifikan dan konsumsi karbohidrat yang tinggi. Selama tinggi genangan tidak terlalu jauh diatas pucuk tanaman, padi rawa ini mampu memunculkan pucuk ke permukaan air dengan percepatan pemanjangan ruas. Namun, apabila tinggi permukaan air jauh di atas pucuk tanaman, padi ini akan mengalami krisis energi yang mematikan sebelum mampu keluar dari rendaman. Sebaliknya, padi tadah hujan yang toleran genangan (submergence-toleran lowland rice) dapat beradaptasi terhadap ketinggian genangan yang mematikan bagi padi rawa. Pada varietas toleran ini, etilen yang diinduksi genangan meningkatkan (up-regulation) faktor responsif etilen, gen SublA yang menurunkan biosintesis selama genangan. Ekspresi SublA yang cukup membatasi akumulasi mRNA responsif etilen dan pemanjangan sel serta kaabolisme karbohidrat. Dengan demikian, respon terhadap genangan dengan mediasi etilen, seperti pemanjangan dan konsumsi karbohidrat, ditekan selama stress (Fukao \& Serres, 2008).

\section{BIOSINTESIS DAN PERANANNYA DALAM PEMANJANGAN RUAS}

Menurut Fukao \& Serres (2008), ada dua enzim yang sangat penting dalam biosintesis etilen, yaitu ACC sintase (ACS) dan ACC oksidase (ACO). Enzim ACS mengkatalis perubahan S-adenosyl-L-Mehionine (SAM) menjadi 5`-methylthioadenosine (MTA) dan ACC, prekusor sementara etilen.

Ulasan Vriezen et al., (2003) menjelaskan bahwa biosintesis etilen diatur oleh gen ACC sintase (ACS). Pada bibit berumur delapan hari yang tumbuh pada kondisi anaerobik, gen $O S$-ACS1 diperlihatkan sebagai spesifik batang dan gen $O S$-ACS3 sebagai spesifik akar. Pada genangan penuh bibit umur 9 hari, gen OS-ACS5 terekspresi di dalam batang. OS-ACS5 mRNA menumpuk dalam waktu 1 jam setelah genangan hingga lebih besar dari OS-ACS1. OS-ACS5 mRNA dilokalisasi dalam jaringan dan sel khusus baik dalam keadaan normal maupun dalam merespon genangan penuh. Ekspresi OS-ACS5 dianalisa dengan hibridisasi in situ dan histokimia aktifitas $\beta$-glucuronidase (GUS) dalam tanaman padi transgenic yang membawa OS-ACS5-GUS. 


\section{Review}

\section{Versi pre-print}

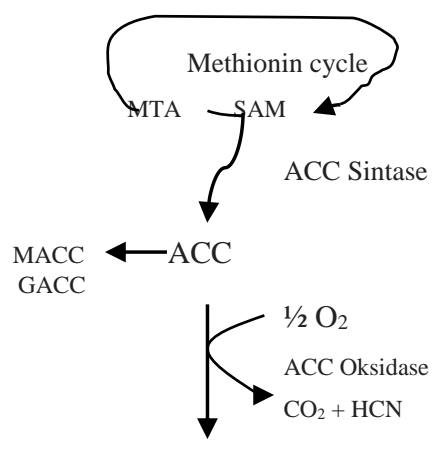

Ethylene

Gambar 2. Skema biosintesis etilen. SAM (S-adenosyl-LMehionine), MTA (5-methylthioadenosine), ACC (1aminocyclopropane-1-carboxylic acid), MACC (1-malony aminocyclopropane-1-carboxylic acid), GACC (1glutamyaminocyclopropane-1-carboxylic acid) Sumber: Vriezen et al., (2003)

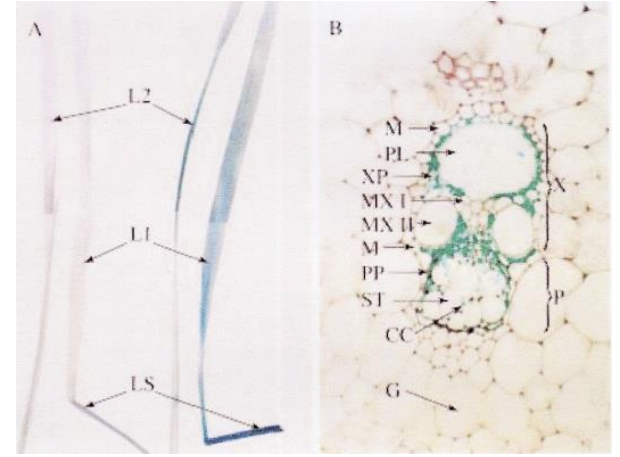

Gambar 3. A. bibit padi yang ditanam pada keadaan aerobik (kiri), OS-ACS5-GUS terekspresi sedikit pada daun (LS) dan dalam merespon genangan penuh ekspresinya dalam berkas pembuluh daun muda sangat kuat (kanan). B. berkas pembuluh dalam daun tua (umur 8 minggu). Sel parenkima floem (PP) mengelilingi sieve tube (ST) dan sel companion (CC) dalam floem menunjukkan ekspresi GUS. Juga sel parenkima xylem tipis (XP) yang membungkus rongga protoxilem (PL) dan sel parenkima xylem tebal (XP) yang berhubungan dengan pembuluh metaxilem (MX) menunjukan aktifitas GUS.

CC, Companion cell; G, Ground tissue; L (1 or 2), leaf (first or second); LS, Leaf Sheath; M, Mestome sheath; MX, Metaxylem vessel; P, Phloem; PL (Protoxylem lacuna; PP, Phloem Parenchyma cell; ST, Sieve Tube; X, Xylem; Xp, Xylem parenchyma cell

Sumber: Vriezen et al., (2003)

Penelitian dengan perlakuan etilen merangsang pertumbuhan ruas tanaman padi rawa (deep-water). Sebaliknya, pertumbuhan varietas non-rawa tidak dirangsang dengan perlakuan etilen. Selama genangan, konsentrasi etilen endogen meningkat menjadi $1 \mu \mathrm{l} \mathrm{l}^{-1}$, suatu konsentrasi yang cukup untuk menrangsang pertumbuhan, juga apabila diaplikasikan secara eksogen pada tanaman ini dalam keadaan tidak tergenang.

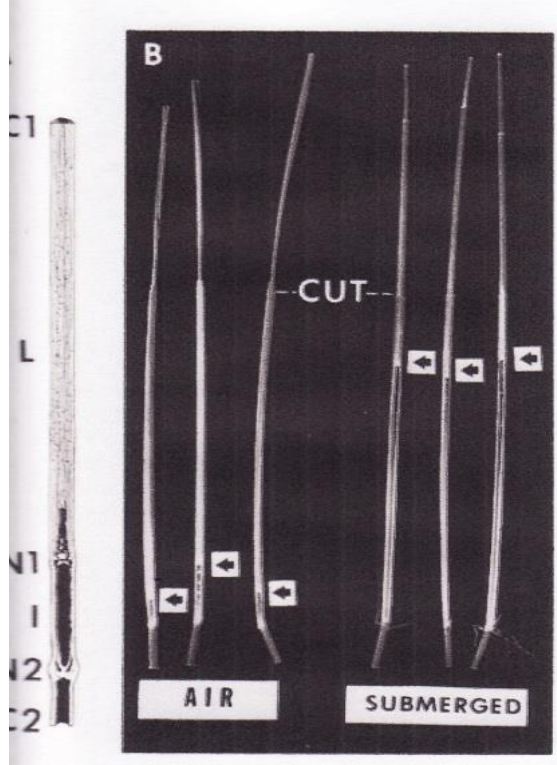

Gambar 4. Morfologi padi rawa (deep-water) pada kondisi aerobic dan anaerobic (direndam).

A. Penampang membujur sepanjang $20 \mathrm{~cm}$ batang padi. Buku tertinggi kedua (N2) berada pada $2 \mathrm{~cm}$ diatas dasar potongan (C2). Buku yang dibawa dipisahkan dari buku teratas (N1) oleh ruas termuda (I). bagian batang diantara buku tertinggi dan potongan atas $(\mathrm{C} 1)$ terdiri dari helai daun dan daun muda yang sedang berkembang.

B. Bagian yang telah diinkubasi dalam genangan dan aerobic. Setelah 3 hari, bagian tanaman ini diukur panjang ruasnya. Posisi buku tertinggi (N1) ditandani dengan tanda panah dan potongan atas (C1) ditandai CUT 
Review

Versi pre-print

Tabel 1. Konsentrasi $\mathrm{O}_{2}, \mathrm{CO}_{2}$ dan $\mathrm{C}_{2} \mathrm{H}_{4}$ dalam rongga ruas batang tanaman padi yang dialiri udara dan digenangi air

\begin{tabular}{|c|c|c|c|c|}
\hline \multirow[t]{2}{*}{ Gas } & \multicolumn{2}{|c|}{ Submerged } & \multicolumn{2}{|c|}{ Air control } \\
\hline & $\begin{array}{l}\text { End } \\
\text { of } 2 \mathrm{nd} \\
\text { dark } \\
\text { period }\end{array}$ & $\begin{array}{l}\text { Middle } \\
\text { of 3rd } \\
\text { light } \\
\text { period }\end{array}$ & $\begin{array}{l}\text { End } \\
\text { of } 2 \mathrm{nd} \\
\text { dark } \\
\text { period }\end{array}$ & $\begin{array}{l}\text { Middle } \\
\text { of } 3 \mathrm{rd} \\
\text { light } \\
\text { period }\end{array}$ \\
\hline $\mathrm{O}_{2}(\%, \mathrm{v} / \mathrm{v})$ & 2.1 & 7.4 & 19.7 & 22.1 \\
\hline $\mathrm{CO}_{2}(\%, \mathrm{v} / \mathrm{v})$ & 6.7 & 1.1 & 1.6 & 0.06 \\
\hline $\mathrm{C}_{2} \mathrm{H}_{4}\left(\mu \mathrm{ll}^{-1}\right)$ & 1.0 & 0.9 & 0.01 & 0.01 \\
\hline
\end{tabular}

Sumber: Raskin \& Ende (1984)

Gambar 4B diatas menunjukkan morfologi tanaman setelah perlakuan. Kedua perlakuan menghasilkan tinggi tanaman yang sama. Namun, apabilah di belah akan terlihat perbedaan lokasi pemanjangan. Pada tanaman control, pemanjangan terjadi pada daun. Semetara pada tanaman yang terendam, pemanjangan terjadi pada ruas. Pemanjangan ruas dirangsang dengan kuat sementara pemanjangan daun dihambat. Perangsangan pemanjangan ruas dan penghambatan pemanjangan daun pada padi rawa yang tergenang disebabkan meningkatnya sintesis etilen dalam jaringan ruas dan akumulasi etilen rongga batang yang terendam. Hal ini juga dapat dibuktikan oleh Tabel 1 dan Tabel 2 dimana konsentrasi etilen pada rongga ruas batang yang terendam lebih tinggi dibandingkan dengan kadar etilen yang ada dalam rongga ruas batang kontrol.

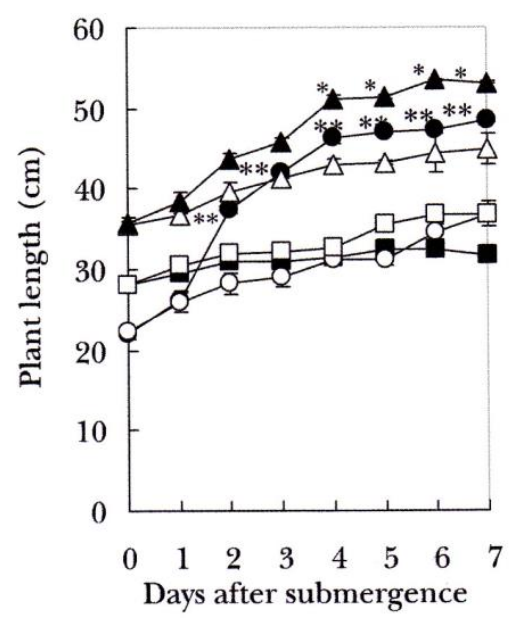

Gambar 5. Tinggi tanaman pada tanaman terendam dan control. Bulat, segitiga dan kotak secara beturut-turut menggambarkan Saligbeli, Ballawe dan IR 49830-7-1-2-2 (varietas toleran); hitam dan kosong secara berturut-turut menggambarkan terendam dan control; * dan ** mengindikasikan berbeda nyata terhadap control pada taraf nyata 0,05 dan 0,1 .

Sumber: Kawao et al. (2008)

Tabel 2. Rata-rata panjang ruas padi rawa dengan pemanjangan antara $0-3$ hari

Cara sitasi: Sagala, Danner. 2017. "Adaptasi Tanaman Padi Terhadap Stres Genangan: Biosintesis Etilen”. INA-Rxiv. December 17. osf.io/preprints/inarxiv/xdhrv 
Review

Versi pre-print

\begin{tabular}{lll}
\hline $\begin{array}{l}\text { Source of the } \\
\text { internode }\end{array}$ & Treatment & $\begin{array}{l}\text { Length } \\
(\mu \mathrm{m})\end{array}$ \\
\hline Intact plants & Initial & $19.7 \pm 3.8$ \\
& Control & $21.2 \pm 2.2$ \\
& Submerged $\left.^{-1}\right)$ & $31.6 \pm 2.6$ \\
& $\mathrm{C}_{2} \mathrm{H}_{4}\left(1 \mu 1^{-1}\right)$ & $34.8 \pm 5.6$ \\
Stem sections & Initial & $26.4 \pm 7.5$ \\
& Control & $20.3 \pm 2.3$ \\
& Submerged & $70.2 \pm 4.3$ \\
& Ethylene & $81.6 \pm 16.6$ \\
& $3 \% \mathrm{O}_{2}, 91 \% \mathrm{~N}_{2}, 6 \% \mathrm{CO}_{2}$ & $57.0 \pm 16.6$ \\
& $3 \% \mathrm{O}_{2}, 91 \% \mathrm{~N}_{2}, 6 \% \mathrm{CO}_{2}$, & $87.8 \pm 13.8$ \\
& $1 \mu \mathrm{I} \mathrm{I}^{-1} \mathrm{C}_{2} \mathrm{H}_{4}$ & \\
\hline
\end{tabular}

Sumber: Metraux \& Kende (1984)

\section{PENUTUP}

Padi merupakan tanaman semi akuatik yang mampu beradaptasi dengan baik pada lingkungan yang tergenang. Ada dua tipe adaptasi padi yaitu toleran (lowland rice variety) dan penghindaran (deepwater rice variety). Pemanjanangan selama genangan, yang merupakan strategi penghindaran, memampukan tanaman padi untuk memulai/melakukan metabolisme aerobik dengan mengusahakan pucuk berada di atas permukaan air. Pemanjangan ruas ini dipacu oleh fitohormon etilen. Namun, adaptasi ini menggunakan banyak karbohirat dan cadangan energy lainnya sehingga apabila genangan terjadi dalam waktu yang panjang.

\section{DAFTAR PUSTAKA}

Fukao, T. and J.B-Serres. 2008. Ethylen - A Key Regulator of Submergence Response in Rice. Plant Science 175: 43-51. www.science direct.com downloaded December, $10^{\text {th }} 2008$.

Ito, O., E. Ella, N. Kawano. 1999. Physiological Basis of Submergence Tolerance in Rain fed Lowland Rice Ecosystem. Field Crops Research. 64:75-90.

Jackson, M.B., and P.C. Ram. 2003. Physiological and Molecular basis of Suscptibility and tolerance of rice Plants to Complete Submergence. Annals of Botany. 91: 227-241.

Jackson, M.B. 2008. Ethylene-Promoted Elongation: An Adaptation to submergence Stress. Annals of Botany. 101: 229-248.

Kawano, N., E. Ella, O. Ito, Y. Yamauchi, K. Tanaka. 2002. Metabolic Changes in Rice Seedlings with Different Submergence Tolerance after Desubmergence. Environmental and Experimental Botany. 47: 195-203.

Kawano, N., O. Ito, and J. Sakagami. 2008. Relationship Between Shoot Elongation and Dry Matter Weight During Submergence in Oryza sativa L. and O. glaberrima Steud. Rice Cultivar. Plant Prod. Sci. 11(3): 316 - 323. 
Review

Versi pre-print

Litbang Deptan. 2007. IRRI Temukan Varietas Padi Tahan Banjir. http://www.litbang.deptan.go.id didownload pada tanggal 6 Oktober 2008.

Metraux, J., and H. Kende. 1984. The Cellular Basis of elongation response in Submerged Deep-water Rice. Planta. 160: 73-77.

Raskin, I., and H. Kende. 1984. Regulation of Growth in Stem sections of Deep-water Rice. Planta. 160: 66-72.

Ram, P.C., B.B. Singh, A.K. Singh, P. Ram, P.N. Singh, H.P. Singh, I. Boamfa, F. Harren, E. Santosa, M.B. Jackson, T.L.Setter, J. Reuss, L.J. Wade, V. Pal Singh and R.K. Singh. 2002. Submergence Tolerance in rainfed Lowland Rice: Physiolgical basis and Prospects for Cultivar Improvement through marker-Aided Breeding. Field Crops Research. 76: 131-152

Vriezen, W.H., Z. Zhou, D. Van Der Straeten. 2003. Regulation of Submergence-induced Enhanced Shoot Elongation in Oriza sativa L. Annals of Botany. 91: 263-270. 